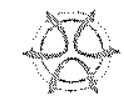

PLANNING MALAYSIA

Journal of the Malaysian Institute of Planners (2008) VI, $75-100$

\title{
ROLE OF LAND USE PLANNING IN IMPROVING PUBLIC HEALTH: WAY FORWARD FOR MALAYSIA
}

\author{
Ainul Jaria Maidin ${ }^{1}$ \\ Ahmad Ibrahim Kulliyyah of Laws \\ INTERNATIONAL ISLAMIC UNIVERSITY MALAYSIA
}

\begin{abstract}
It is an undeniable fact that land use planning regulatory framework and concern for improving living and built environment originated from the desire to improve public health. Planning issues remained at the root of some of the most intractable public health problems, including the declining rates of physical activity resulting from automobile-dependent environments or the isolation of poor and minority communities in areas plagued by environmental pollutants, violent crime, and high rates of disease. Land use, community design, and transportation systems substantially impact local air quality, water quality and supply, traffic safety, physical activity and exposure to contaminated industries. Mental health and quality of life issues also are profoundly affected by factors ranging from the stress and difficulties of commuting to the presence or absence of natural areas and green spaces. There is a general realization that health specialists or planning departments cannot afford to operate in isolation from one another. This article intends to examine the important role that can be assumed by the members of local health department and other public health professionals in protecting local environmental health and improving the health of the communities through land use planning.
\end{abstract}

Keywords: Land use planning, Public health, Legal framework, Local authorities, Malaysian land planning system

\section{INTRODUCTION}

The close link between land use and environmental planning to human health is undeniable. Indiscriminate land use development activities can lead to environmental degradation and subsequently adverse impact on public health. The built environment significantly affects the public's health. This was most

1 Assistant Professor, Public Law Department, Ahmad Ibrahim Kulliyyah of Laws, International Islamic University Malaysia, LL.B (Hons.) (IIUM); Master in Comparative Laws (IUM); Ph.D. (UWA, UK); Advocate and Solicitor, High Court of Malaya. 
obvious when infectious disease was the primary public health threat during the industrial revolution; unsanitary conditions and overcrowded urban areas facilitated the spread of infection. However, even today in the age of chronic diseases there remains an important connection between population health and the built environment. Physical spaces can expose people to toxins or pollutants and influence lifestyles that contribute to diabetes, coronary vascular disease, and asthma. Public health advocates can help shape the design of cities and suburbs in ways that improve public health, but to do so effectively they need to understand the legal framework. This article reviews the connection between public health and the built environment and then describes the legal pathways for improving the design of our built environment. ${ }^{2}$ Land and natural resources development is essential for promoting economic growth in Malaysia. After achieving independence the Malaysian government has achieved tremendous growth in various sectors, but to a great extent it has undermined issues related to environmental pollution arising from indiscriminate land development. ${ }^{3}$ Sensing this predicament, Trust No.4 of the Ninth Malaysian Plan focuses on the need to improve the standard and sustainability of quality of life. ${ }^{4}$ The plan also emphasizes the importance of the role of the government in providing facilities and implement programmes to improve the health status of the population. However, at the same time, the government did not realize that its vision to create a healthy nation can be realized only if the environment is clean and free from pollutants as well as conducive for the people to socialize and interact within the community to promote unity amongst the multi racial and religious Malaysian people. Health is also a requirement for people to enjoy the fruits of development and to embrace positive attitudes, such as tolerance and caring, as envisaged in "Vision 2020".

The government has under the $9^{\text {th }}$ Malaysian Plan allocated RM510 million for cleaning, preserving and beautifying rivers and RM4 billion for flood mitigation projects in the process of improving the environmental quality. Allocation of big funds in improving the environmental quality is indeed a good move. However, what is important is that the land use planning decisions must be made by involving various stakeholders that is the local planning authorities, public health authorities as well as the general public and the non-governmental

${ }^{2}$ Wendy Collins Perdue, JD, Lesley A. Stone, JD and Lawrence O. Gostin, JD, LLD (Hon), "The Built Environment and Its Relationship to the Public's Health: The Legal Framework," September 2003, Vol.93, No.9, American Journal of Public Health 13901394.

${ }^{3}$ This is evidenced by the various research and reports on the ever increasing environmental problems in Malaysia especially landslides, flash floods loss of fertile land for agriculture to industries, and various types of industrial pollution.

${ }^{4}$ Government of Malaysia, "Chapter 1" Ninth Malaysia Plan 2006 - 2010, at p. 37. 
organisations. Globally, significant progress has been made to control communicable diseases such as malaria, typhoid, hepatitis A, leprosy and tuberculosis through improved sanitation facilities, increased access to safe drinking water and improved dental health. ${ }^{5}$

Various programmes have been planned to promote healthy lifestyles in Malaysia, for instance, in 1991, the Ministry of Health in Malaysia, launched the "Healthy Lifestyle Campaign" with its first thematic campaign, cardiovascular disease. For each consecutive year, one thematic campaign was carried out, such as prevention of diabetes mellitus in 1996 and healthy diet and nutrition in 1997. Community participation and the involvement of nongovernmental organizations have contributed to the success of these programmes. Collaboration with government agencies, e.g. the National Institute of Occupational Safety and Health, has allowed emerging problems related to industrialization and occupational health to be addressed.

There is a general realization that health specialists and land use planning authorities cannot afford to operate in isolation from one another. It is important to examine the important role that can be assumed by members of the health department and other public health professionals in protecting environmental health at all levels and improving the health of the communities by participating in the land use planning, decision making, and development control process. The fading link between the land use planning and health must be re-established otherwise, public health will never be realised. This is done by examining the longstanding connection between the built environment; the way we develop and organize our neighbourhoods, cities, and regions; and the "physical, mental and social well-being"6 of the population. Development in promoting public health at a global level will be explored to examine some suitable recommendations that can help improve the role that can be assumed by the land planning system in Malaysia in promoting public health.

${ }^{5}$ Michael Greenberg, PhD, Henry Mayer, PhD, K. Tyler Miller, Robert Hordon, PhD and Daniel Knee, MCRP, "Reestablishing Public Health and Land Use Planning to Protect Public Water Supplies" September 2003, Vol 93, No. 9, American Journal of Public Health 1522-1526 http://www.ajph.org/cgi/content/full/93/9/1522, accessed on $16^{\text {th }}$ February 2007 citing Tarr J. The Search for the Ultimate Sink: Urban Pollution in Historical Perspective. Akron, Oh: University of Akron Press; 1996; Melosi M. Effluent America: Cities, Industry, Energy, and the Emvironment. Pittsburgh, Pa: University of Pittsburgh Press; 2001; and MacKenzie W, Hoxie N, Proctor M, Gradus M, Blair K, Peterson D. "A massive outbreak in Milwaukee of Cryptosporidium infection transmitted through public water supply" $N$ Engl $J$ Med. 1994; 331:161-167.

6 The World Health Organization defines health as "a state of physical, mental and social well-being, not merely the absence of disease or infirmity." 


\section{ORIGIN OF LAND USE PLANNING - TRACING THE LINK TO PUBLIC HEALTH}

Modern land use planning that originated from the United Kingdom is a result of specific social and economic problems triggered by the Industrial Revolution towards the end of the $18^{\text {th }}$ century. The movement sought to eradicate social problems of overcrowding, poverty, ill health, unemployment, unsanitary and inadequate living accommodation. Urban living environment requires proper planning to help improve the living conditions of the people. The garden city movement was founded by Ebenezer Howard in England in 1898 as an approach to urban planning. Garden cities were to be planned, self-contained communities surrounded by greenbelts, and containing carefully balanced areas of residences, industry, and agriculture. ${ }^{7}$ Thus, early planning efforts were undertaken to control the spread of infectious diseases, and concern for improving living and the built environment to improve public health. Industrialisation and rapid urbanization has influenced many countries and it is now a global phenomenon and Malaysia too is not spared.

In Malaysia, Sir Francis Light is said to have introduced the first formal town planning system in the $18^{\text {th }}$ century Penang. The initial efforts were very much dictated by considerations of public health, fire prevention and generally to facilitate the process of issuing of titles and land-efficient land administration. Later the Sanitary Board of Kuala Lumpur was established in 1890 with the objective of taking care of public health interests as well as to manage all related affairs of the growing urban settlement. ${ }^{8}$

Planning itself is a multi-objective, multi-dimensional, multi-disciplinary and multi-decision making activity and process. It has developed into a comprehensive exercise of analysis and prescription covering the regulation of environmental and community affairs far beyond its early purpose. It has evolved beyond being a simple technical exercise of land selection and physical design and has broadened into an activity of social purpose where the shaping of the physical environment is emphasized.

${ }^{7}$ Inspired by the Utopian novel Looking Backward, Howard published To-morrow:a Peaceful Path to Real Reform in 1898 (reissued in 1902 as Garden Cities of Tomorrow), organized the Garden City Association in 1899, and founded two cities in England: Letchworth Garden City in 1903, and Welwyn Garden City in 1920. Both designs are durable successes and healthy communities today, although not a full realization of Howard's ideals. The idea of the garden city was influential in the United States.

${ }^{8}$ Refer Ahmad Kamal Arifffin Mohd Rus, Sanitary Board Kuala Lumpur - Peranan dan Pentadbiran 1890-1914, Persatuan Sejarah Malaysia, Kuala Lumpur, 2001. 
The process is not merely limited to layout plans of residential, industrial, commercial or recreational activities, but a combination of components and elements which help to create a holistic living, working and recreational environment which in total determines the quality of human life and as an important tool in promoting national unity, and economic development.

Planning issues remain at the root of some of the most intractable public health problems, including the declining rates of physical activity resulting from motor vehicles dependent environments or the squatters who make up the slum dwellers especially in areas plagued by environmental pollutants, violent crime, and high rates of disease. Land use, community design, and transportation systems substantially impact local air quality, water quality and supply, traffic safety, physical activity and exposure to contaminated industries. ${ }^{9}$ Mental health and quality of life issues also are profoundly affected by factors ranging from the stress and difficulties of commuting to the presence or absence of natural areas and green spaces. ${ }^{10}$ Environmental health and chronic diseases such as obesity and physical inactivity are two of the most significant public health challenges of the $21^{\text {st }}$ century. However, now we seem to have parted from the original aims of land use planning process.

Public health is concerned with threats to the overall health of a community based on population health analysis. Health is defined and promoted differently by many organizations. The World Health Organisation, the United Nations body that sets standards and provides global surveillance of disease, defines health as: "A state of complete physical, mental and social well-being and not merely the absence of disease or infirmity." In some ways, public health is a modern concept, although it is said to have been around since time immemorial. From the early beginning of human civilization, it was recognized that polluted water and lack of proper waste disposal may spread vector-borne diseases. Even religions attempt to regulate behavior that is specifically related to health, from types of food eaten, and the extent which certain behaviors could be indulged,

9 "Pollution and Health", Chapter 3, in Meeting the Urban Challenge, Population Reports, Volume XXX, Number 4, Fall 2002 Series M, Number 16 Special Topics Internet Edition http://www.infoforhealth.org/pr/m $16 / \mathrm{ml}$ l6hap $3 . \mathrm{shtml}$ accessed on 10 October 2006.

${ }_{10}$ Public Health in Land Use Planning and Community Design, fact sheet of the National Association of County and City Health Officials, 2005.

"WHO Definition of Health Preamble to the Constitution of the World Health Organization as adopted by the International Health Conference, 1946. 
such as consuming alcohol or drugs. ${ }^{12}$ The governments of countries has been empowered to develop public health policies and programs to gain some understanding of the causes of disease to ensure stability, prosperity, and maintain order. Climate change has had a negative effect on public health as it can cause changes in the geographical range of disease organisms and vectors, the quantity of air, food, and water; and the stability of the ecosystems on which we depend. ${ }^{13}$ The United Nation's intergovernmental Panel on Climate Change and other scientific panels have assessed the potential health consequences of climate change. ${ }^{14}$

\section{LINKING LAND USE PLANNING, NATURAL RESOURCES CONSERVATION AND PUBLIC HEALTH}

Decisions on land use and community design impacts tremendously on a wide range of health and environmental issues. Land use policies can have unintended consequences that may impact adversely upon the public health ranging from obesity to chronic diseases such as heart disease, diabetes, cancer, psychological stress, and motor vehicle related injuries. ${ }^{15}$ Health is affected to a great measure by environmental conditions. The World Health Organisation defines environment and health as including both the direct pathological effects of chemicals, radiation and some biological agents, and the effects on health and well-being of the broad physical, psychological, social and aesthetic environment, which includes housing, urban development, land use and transport. ${ }^{16}$ Environment-related diseases continue to afflict many people,

12 Islam prohibits the drinking of alcohol for Muslims including the consuming of certain types of food on the basis of health. Similarly various other religious also effectively promotes the same.

${ }^{13}$ See World Resources Institute [WRI] et al., World Resources 1998-99, at 67 (1998) stating that climate influences many health determinants and while substantial climaterelated health effects are predicted for the future, making such predictions is an inexact science.

${ }^{14}$ See generally WHO et al., Climate Change and Human Health 99 (A.J. McMichael et al. eds., 1996) (prepared by M. Ando et al. (assessing and predicting the potential impacts of climate change on various infectious diseases. For more information specifically related to climate changes and heat waves, see Nat'l Health Assessment Group, Climate Change and Human Health (May 2001) where it was stated that one of the direct impacts of climate change on human health has been an increase in the severity of heat waves, resulting in increased mortality rates due to heat stress.

is National Environmental Health Association (NEHA) "Land Use Planning \& Design Program," Joumal of Envirommental Health, January 1, 2006.

16 See generally WHO Regional Office for Europe [WHO ROE], Enviromment and Health: The European Charter and Commentary (1989). 
particularly the poorer section of the world population. ${ }^{17}$ For example, diarrhoeal diseases, largely preventable through access to safe drinking water, sanitation and food hygiene, claim 1.5 million lives a year. ${ }^{18}$ At the beginning of 2000 , a substantial portion of the world's population was without access to improved water supply and sanitation. ${ }^{19}$ Africa and Asia are two parts where this problem is particularly rampant. ${ }^{20}$

Air pollution is associated with a variety of health risks including acute respiratory infections such as asthma, pneumonia. ${ }^{21}$ Air pollution can transcend national and international environmental health concerns, as illustrated by air pollution episodes, such as the forest fires in Sumatera that affects all countries in South East Asia. Ecosystem and health focuses on the maintenance and restoration of the world's ecosystems as an essential determinant of human health and considers human health as one of the elements of sustainability. People from the developing nation are always prone to diseases ${ }^{22}$ owing to increases in population, travel, trade, and an unsustainable increase in utilization of natural resources. In the wake of the severe acute respiratory syndrome ("SARS"), it is becoming apparent that trade in wildlife, even within the

${ }^{17}$ See World Resources Institute [WRI] et al., World Resources 1998-99, at 1 (1998); See also Kirk R. Smith et al., "How Much Ill Health Is Attributable to Environmental Factors?," 10 Epidemiology 573, 573, 581-83 (1999) stating that an estimated "25-33\% of the global burden of disease can be attributed to environmental risk factors," and that this percentage decreases with economic development, meaning that people in developing countries are prone to risk.

18 See WHO, "Health in the Context of Sustainable Development," at 67, WHO Doc. WHO/HDE/HID/02.6 (2002) (prepared by Y. von Schirnding \& C. Mulholland stating that climate influences many health determinants and while substantial climate-related health effects are predicted for the future, making such predictions is an inexact science)..

${ }^{19}$ See WHO, ibid, at 16 reported that 1 billion people are without access to improved water supply, and 2.4 billion lack access to improved sanitation; see also WHO, Health for All in the Twenty-First Century p 26 (1998).

${ }^{20}$ See WHO \& UNICEF, "Fewer than one-half of all Asians have access to improved sanitation and two out of five Africans lack improved water supply."

21 William Onzivu, "International Environmental Law, the Public's Health, and Domestic Environmental Governance in Developing Countries," 2006, 21 American University International Law Review p.597, at p.603.

${ }^{22}$ See WHO Press Release, "Avian Influenza - Situation (Birds) in Nigeria," Feb. 8, 2006, http:/www.who.int/csr/don/2006 02 08/en/ Refer also William Onzivu, "Globalism, Regionalism, or Both: Health Policy and Regional Economic Integration in Developing Countries, an Evolution of a Legal Regime?," 15 Minn. J. Int'l L. 111, 115 (2006) where the author discussed the increasing need to place health on the global and regional agenda in light of recent disease outbreaks around the world. 
limitations imposed by the Convention on International Trade in Endangered Species of Flora and Fauna, poses a threat to public health. ${ }^{23}$

A series of recent reports have emphasised the importance of reconnecting planning and public health. For instance the National Centre for Environmental Health of the Centres for Disease Control and Prevention in its report, Creating a Healthy Environment: The Impact of the Built Environment on Public Health ${ }^{24}$ argued the need to reintegrate land use planning and public health. The report linked explicitly transportation and land use planning to public health outcomes such as increased obesity, asthma and mental health. In 1999, the World Health Organisation published a report on, Healthy Cities and the City Planning Process, emphasised the importance of developing a model of "healthy urban planning" to ensure the health of the world's increasing urban and poor populations. ${ }^{25}$ Healthy People 2010 list eliminating health disparities as 1 of its 2 top priorities and acknowledges that only an interdisciplinary approach to health promotion will accomplish this goal. ${ }^{26}$

These reports provide an important step towards reuniting planning and public health, however, what is missing is an articulation of the challenges each field must confront in any reconnection effort and a theory or framework articulating why and for whom the fields should be reconnected. ${ }^{27}$ The most important issue at present is that the divide between land use planning and public health must not be allowed to develop further. This will cause further negative impact on public health.

\footnotetext{
${ }^{23}$ See Mary C. Pearl, "Editorial, Wildlife Trade: Threat to Global Health," 1 Eco Health 111 (2004) where the author was asserting that many wild exotic animals bring with them an enormous risk of diseases and parasites and yet despite regulations, the wildlife trade is approximately a six billion dollar activity.

${ }^{24}$ Jackson RJ, Kochtitzky C., "Creating a Healthy Environment: The Impact of the Built Environment on Public Health." Internet Edition at http:/www.sprawlwatch.org. Accessed November 2006.

${ }^{25}$ DuhI LJ., Sanchez AK, Healthy Cities and the City Planning Process, Internet Edition at http:/www.who.dk/docment 843pdf. Accessed on 20th November 2006.

${ }^{26}$ Healthy People 2010, Washington, DC.:US Dept of Health and Human Services, 2000.

${ }^{27}$ Jason Coburn, "Confronting the Challenges in Reconnecting Urban Planning and Public Health," in American Journal of Public Health, 2004 April; 94(4):541-546 Internet Edition at http:/www.ajph.org/. Accessed on January 2007 the author highlighted some of the challenges posed to the efforts of reconnecting urban planning and public health.
} 


\section{Malaysian National Land Use Planning and Development Control System}

The planning system in the Peninsular Malaysian states, is regulated by the Town and Country Planning Act 1976 (Act 172), and the rules made by the National Physical Planning Council and the State Authority and the standards and guidelines formulated by the Director General of Town and Country Planning to provide further guidance on matters related to town and country planning. It is subject to the supervisory powers of authorities including the National Physical Planning Council at the Federal level, the State Planning Committee at the state level and the local planning authority at the local government level. The basis of control of town and country planning is the development plans, which is aimed at regulating and controlling the use and development of land. The respective State Directors for Town and Country Planning formulates and keep under review the structure plans of general policy for their areas, and the other authorities maintain local plans of detailed policy for theirs. The machinery of control is planning permission, without which no development of land will be permitted. To date, the Town and Country Planning Act 1976 has been amended thrice to principally improve the quality of urban living and environment. The first amendment was in 1993 to ensure the incorporation of provisions on sewerage in the development planning process in line with the enactment of the Sewerage Services Act.

The second amendment in 1995 was made to incorporate various environmental protection measures in the land use planning process in order to promote sustainable development. This was principally to address the weaknesses in the town and country planning system that is believed to have culminated in the Highland Towers Tragedy on the $11^{\text {th }}$ December 1993. Significantly, the amendment introduced the need to prepare a development proposal report for all land development activities to ensure environmental impacts are considered in the development planning process. The amendment introduced the Tree Preservation Order to promote preservation and protection of trees; provision for promoting preservation and improvement of physical environment; preservation of natural topography of an area; improvement of landscape; creation of open spaces; preservation and enhancement of heritage building and management of traffic for promoting quality and healthy urban living.

The latest amendment in 2001 was made to promote and balance the sharing of powers between the Federal and State government in the process of land use and natural resources planning and environmental protection. The amendment provided for the establishment of the National Physical Planning Council chaired by the Honourable Prime Minister at the Federal government level. The Council is expected to coordinate development at the national level so as to 
promote sustainable development for the country. The amendment also introduced various measures to promote sustainable development and coordination of development at all levels of the government. The Council with the assistance from the Director General of Town and Country Planning and his department is expected to strengthen the role of the town and country planning process as a mechanism to promote sustainable development for the betterment of the nation including providing means for improving public health. The need to establish a regional planning unit was addressed and thus, the amendment incorporated the provision for establishing a regional planning committee for purposes of coordinating development within regions. This is an important development as it addresses effective utilisation of natural resources and prevents wastage and overlapping of developmental activities.

\section{Challenges within the land use planning system}

The following are some of the challenges or barriers posed to the administration system in the process of promoting health issues in the land use planning and development control system generally, and in Malaysia specifically:

a. Lack of good quantitative data, particularly on the local level; National data is available, but local data would be significant for making the case on the political level. Also, an over-reliance on quantitative data might mean that other health problems of equal importance are not equally validated.

b. Lack of cross-disciplinary education and collaboration. There is no onestop supervisory agency that unites all parties involved in the land-use planning process.

c. Processes within the land use planning and development control are compartmentalized. The recommendations made by all the various authorities involved in the process are often not taken into consideration since the ultimate decision making power resets with the planning authorities.

d. Health is often too narrowly defined and it doesn't relate obesity, physical activity, asthma, and other related health problems to affordable housing, unsanitary living conditions etc. Health issues focus more on finding cure for illness without looking at the sources.

It would be useful to examine the developments in promoting protection for public health at global level that could provide some useful suggestions towards improving the Malaysian land use planning system in improving public health. 


\section{Developments in promoting protection for public health at global level}

A number of principles emerged from the 1992 U.N. Conference on Environment and Development ("UNCED"), other declarations, and conventions, have supported the development of international environmental law. These principles include the concept of sustainable development ${ }^{28}$ the principle of intergenerational equity ${ }^{29}$ and intra-generational equity ${ }^{30}$ the right to a clean environment, ${ }^{31}$ the polluter-pays principle, ${ }^{32}$ the precautionary principle, ${ }^{33}$ and the practice of environmental impact assessments. ${ }^{34}$ The 1972

${ }^{28}$ Refer Report of the United Nations Conference on Environment and Development, June 3-14, 1992, Rio Declaration on Environment and Development, Annex I principle No. 4, U.N. Doc A/CONF.151/26 (Vol. I) (1992) ["Rio Declaration"] where it was declared that environmental protection constitutes an integral aspect of sustainable development.

${ }^{29}$ Several Principles from the Rio Declarations support an intergenerational model of development. Principle No. 3 asserts that an equitable right to development is essential to fulfill the needs of present and future generations; Principles 5-7 urges all people and nations to cooperate in a global partnership to eradicate poverty, assist vulnerable populations, and reduce environmental degradation; Principle No.11 urges states to enact effective and appropriate environmental laws and programs; Principle No. 14 calls on states to prevent transfer of harmful material to other states.

${ }^{30}$ Rio Declaration Principle 21 urges the younger generations to form a creative global partnership in support of sustainable development.

${ }^{31}$ Rio Declaration Principle No.1 pronounced that under a sustainable development model all people are entitled to a healthy environment; see also United Nations Conference on the Human Environment, June 5-16, 1972, Declaration of the United Nations Conference on the Human Environment, Principle No.1, U.N. Doc. A/CONF.48/14/Rev.1 (1973) ["Stockholm Declaration"].

32 Rio Declaration, Principle No.16 states that a polluter should bear the cost of pollution unless such an action would impede international trade or investment) see also United Nations Conference on Environment and Development, June 3-14, 1992, Agenda 21 Programme of Action for Sustainable Development, P 8.28, U.N. Doc. A/CONF.151/26 (1992) ["Agenda 21"] reported that that several countries have moved toward market-oriented approaches such as having the polluter or natural resource-user pay.

33 Rio Declaration, Principle No.15 urges states to adopt precautionary measures to protect the environment; see also Agenda 21, at pp 9.6-.8 where it listed several precautionary actions that states can take to protect the environment such as increased research, balanced climate observation, scientific capacity building, and identification of climate fluctuations.

34 Rio Declaration, Principle No.17 encourages states to craft a policy of national environmental impact statements that note activities likely to adversely affect the environment. 
United Nations Conference on Human Environment held in Stockholm noted the continuing degradation of the environment and spearheaded the move toward more intensified international action based on the recognition of the health dimension of environmental issues. ${ }^{35}$ Though the Stockholm Declaration did not provide for a specific health agenda, it laid the groundwork for health within the environmental agenda. ${ }^{36}$ Subsequently, the World Commission on Environment and Development (Brundtland Commission and the report, Our Common Future) in 1992, the U.N. Conference on Environment and Development took place. The Report of the World Commission on Environment and Development and UNCED in Rio de Janeiro led to; inter alia, the adoption of Agenda 21. Principle 1 of the Rio Declaration on Environment and Development established a foundation for linking human rights and environmental protection, declaring that man has a fundamental right to freedom, equality and adequate conditions of life, in an environment of a quality that permits a life of dignity and well-being. ${ }^{37}$ It also announced the responsibility of each person to protect and improve the environment for the present and future generations. ${ }^{38}$

The Declaration is said to have laid down a sound foundation for the protection of public health in the realm of a global environmental agenda. ${ }^{39}$ Agenda 21, resulting from the Rio Declaration provided for the need to protect and promote human health, with emphasis on meeting primary health care needs particularly in rural areas to control communicable diseases, the protection of the health of vulnerable groups, addressing the urban health challenge, and reducing health risks from environmental pollution and hazards. ${ }^{40} \mathrm{By}$ emphasizing the need for preventive efforts for health and sustainable development, Agenda 21 provided a mandate for WHO and other health actors to promote health through, interalia, international environmental law.

\footnotetext{
${ }^{35}$ Stockholm Declaration, Preamble discusses the magnitude of human-made problems in the environment that have adverse effects on physical, mental, and social health.

${ }^{36}$ The Conference adopted three non-binding instruments, a resolution on institutional and financial arrangements, the Stockholm Declaration containing twenty-six principles, and an action plan containing 109 recommendations.

${ }^{37}$ Rio Declaration, Principle No.1.

${ }^{38}$ Rio Declaration, Principle No.I.

39 William Onzivu, "International Environmental Law, the Public's Health, and Domestic Environmental Governance in Developing Countries," 2006, 21 Am. U. Int'l L. Rev. 597 at p.14.

${ }^{40}$ Agenda 21, pp.6.1-6.46.http://www.un.org/esa/sustdev/documents/agenda21/index.
} 
Agenda 21 and the Rio Declaration set the basis for integration of health in sustainable development, ${ }^{41}$ affirming that sustainable development maximizes human potential while protecting the environment but that if there is a conflict, human welfare must prevail. ${ }^{42}$ Contribution of Agenda 21 to the environmenthealth discourse has been to expand on the narrow attention devoted to the environment as a source of disease to a wider inclusion of medical care, preventive medicine, and the general improvement of human health. In this way, Agenda 21 reflects the WHO definition of health as "a state of complete physical, mental, and social well-being and not merely the absence of disease or infirmity. ${ }^{143}$ In the developing nations, health is essential for development. ${ }^{44}$ Furthermore, Agenda 21 expounds on the importance of distributive justice and equality in access to basic goods and services as a component of sustainable development.

Public health is concerned with the health of the population as a whole and also concomitant with the concept of redistributive justice in the provision of health services and equitable access to medical care. ${ }^{45}$ Agenda 21 emphasis on enhancing the links between poverty reduction, economic efficiency and sound environmental management is implied. ${ }^{46}$ Agenda 21 strengthens the importance

41 See Agenda 21, "Protection and Promotion of Human Health", in Environment and Development Agenda United Nations Environment Programme, where it was noted that States should use energy sources in a manner that respects both human health and the environment. Refer Internet Edition at http://www.unep.org/Documents.Multilingual/Default.asp?DocumentID $=52 \&$ ArticleID $=54 \& \mathrm{l}=\mathrm{en}$, accessed on $10^{\mathrm{k}}$ May 2007.

42 Rio Declaration, Principle No. 1 declared that humans are the central concern of sustainable development. Internet edition at

http://www.un.org/esa/sustdev/documents/agenda21/index.htm accessed on 10th May 2007.

${ }^{43}$ Constitution of the World Health Organization, July 22, 1946, 62 Stat. 2679, 14 U.N.T.S. 185.

${ }_{44}$ World Health Org., The World Health Report 1999, at 1-12 (1999) at 1-12 where there was finding that poor health conditions increase poverty and that persons with better health contribute to economic growth. Furthermore, research indicates that health indicators such as life expectancy and survival rates are predictors of economic development.

45 Frank P. Grad, "Public Health Law: Its Form, Function, Future, and Ethical Parameters," 49 Int'l Digest Health Legis. 19, 19-22 (1998); see also William Onzivu, Public Health and the Tobacco Problem: International Legal Implications for Africa, 29 Ga. J. Int'l \& Comp. L. 223, 225 (2001).

${ }^{46}$ Ved P. Nanda \& George (Rock) Pring, International Environmental Law for the 21st Century 17-62 (2003), at 103 where the authors argued that the effectiveness with which 
of international health cooperation in dealing with existing and emerging disease pandemics, particularly in developing countries. Agenda 21 thus provides an important basis for the promotion of environmental health through the application of international environmental law at both the global and national spheres. ${ }^{47}$ Thus, during the World Summit on Sustainable Development in 2002, health was one of the five key priorities of the Summit. ${ }^{48}$ In the Summit's Plan of Implementation, the parties agreed to a number of healthrelated goals enshrined in the Millennium Goals. From the 1972 United Nations Conference on the Human Environment in Stockholm to the World Summit on Sustainable Development in 2002, the role of international environmental law in promoting public health has progressively gained prominence internationally and domestically within States. An increased partnership between health and environment sectors has continued to advance environmental health goals while international environmental law is considered effective in achieving public health goals. ${ }^{49}$

Agenda 21 is actually funded and implemented will determine whether this ambitious document is successful.

${ }^{47}$ See Agenda 21, P 1.3; see Yasmin von Schirnding et al., International Environmental Law and Global Public Health 80 Bull. World Health Org. 970, 970 (2002), available at http://www.scielosp.org/scielo.php?script=sciarttext\&pid=S0042-96862002001200012

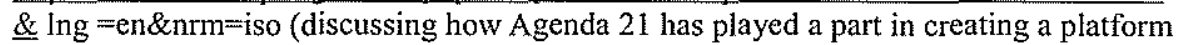
for WHO to promote health through international environmental law); Yasmin von Schirnding, "The World Summit on Sustainable Development: Reaffirming the Centrality of Health, Globalization \& Health 1," 1 (May 10, 2005)

http://www.globalizationandhealth.com/content/pdf/1744-8603-1-8.pdf.

${ }^{48}$ Refer Yasmin von Schirnding, "The World Summit on Sustainable Development: Reaffirming the Centrality of Health, Globalization \& Health 1," at p.4 (May 10, 2005), http://www.globalizationandhealth.com/content/pdf/1744-8603-1-8.pdf.

${ }^{49}$ Yasmin von Schirnding et al., "International Environmental Law and Global Public Health", 80 Bull. World Health Org. 970, 972-73 (2002) at 972-73 where they discussed the contribution of international environmental conventions to the promotion of global public health through technical and financial support and through effective linkages for health. Refer also A. Karim Ahmed, Ph.D., "Environmental Protection, Public Health and Human Rights - An Integrated Assessment," A Report Prepared for Science and Human Rights Program American Association for the Advancement of Science April 2003 (Global Children's Health and Environment Fund National Council for Science and the Environment Internet Edition at http://shr.aaas.org/hrenv/docs/ahmed.pdf, accessed on $20^{\text {th }} \mathrm{Mac} 2007$ (The report evaluated the human rights dimensions of significant environmental and public health issues by: (1) showing linkages between environment, health and human rights within the context of sustainable development; (2) outlining and assessing environmental and public health problems in various regions of the globe; and (3) examining relevant scientific and technical documents, regulatory standards/guidelines, and international treaties and conventions.) 


\section{SUGGESTIONS FOR REFORMS TO LAND USE PLANNING SYSTEM TO PROMOTE PUBLIC HEALTH}

There are various developments regionally and worldwide that has been used to promote incorporation of measures to improve public health. The following are some of the suggestions that could be used to improve the Malaysian system specifically and others generally:

\section{Providing Clear Regulations to Empower Statutory Authority}

Regulations needed are those that provide both clear statutory authority for public health in land-use planning processes and that assures that specific considerations are incorporated into the process. Local public health agencies need more education on how to increase their influence in the land use planning arena along with developing an understanding for urban and transportation design. Need for cross-educational initiatives amongst planners, public and environmental health officials, traffic engineers, community members and the leadership of professional organizations. National organizations can play a collaborating role between public health and land use planning/community design. Build local capacity and provide data and public health benchmarks for safe and health community design. Public Health professionals need to move from working just on the implementation phase of community design to participating as well as the visioning and policy phase; becoming more proactive and involved early on in the process. They should also improve the training and technical support for local public health agencies and other public health professionals on issues of health, the built environment and land use planning and community design processes.

\section{Extending the Role of Health Authority in Decision Making Process}

Currently the health authority is merely given the role of endorsing the development plans prepared by the local planning authority. They assume a reactive role rather than a proactive role as they come in late into the review process, only being asked to make their recommendations. They are not actually involved in the decision making process. Thus, providing them the opportunity to be involved in the planning decision -making process can bring about the changes as they can provide input on information related to public health. Lack of good quantitative data, particularly on the local level despite the availability of data at the National level, is a drawback since local data is what would be significant for decision making. The planning decision- making process is 
compartmentalised as such health authorities are brought in at the end of the reviewing process, and are thus unable to make the desired impact on the decision. The health authorities must be involved at all levels of planning decision making process.

Health authorities can act as the catalysts and facilitators for change in the community. They can initiate community dialogue and use it to promote informed decision-making in relation to community design. Becoming involved early in the land use planning process allows them to play a proactive role. Public Health professionals need to move from working just on the implementation phase of community design to participating, as well, visioning and policy phase; becoming more proactive and involved early on in the process. They must improve the training and technical support for local public health agencies and other public health professionals on issues of health, the built environment and land use planning and community design processes.

\section{Promoting Creation of Healthy City}

The healthy city concept was made popular by the "Healthy for All" movement launched by the World Health Organisation (WHO) in 1978. A healthy city is one which is continually creating and improving those physical and social environments and expanding those community resources which enable people to mutually support each other in performing all the functions of life and in developing to their maximum potential. ${ }^{50} \mathrm{~A}$ healthy city thus is expected to comprise the following characteristics: ${ }^{51}$

1. Planning for provision of basic infrastructure such as sewerage and drainage systems;

2. Planning for the provision of adequate open space;

3. Identification of sites for solid waste disposal and treatment;

4. Provision of adequate land for suitable housing, including squatters improvements;

5. Proper identification of industrial sites;

6. Planning for facilitating sufficient public transportation and reducing traffic congestion; and

50 L.J. Duhl \& A.K. Sanchez, Process A Background Document On Links Between Health And Urban Planning, Internet edition http://www.euro.who.int/document/ e67843.pdf, accessed on $30^{\text {th }}$ May 2007.

${ }^{51}$ Refer Characteristics of a Healthy City outlined in Len Duhl's book, "The Social Entrepreneurship of Change": Internet Edition at http://www.healthycities.org/lenduhls.html, accessed on $20^{\text {th }}$ January 2007. 
7. Protection and improvement of natural beauty areas, natural habitats and cultural heritage.

Urban and rural communities in the world are facing unique challenges. Rapid urbanization and agricultural mechanization have changed the traditional physical and economical set up in the cities and villages. ${ }^{52}$ Migration of the rural population to urban centres has created a strong link between cities and villages. Healthy cities and villages concepts are holistic approaches aiming at improving the quality of environment, thereby the humans, through a focus on the community development such as healthy housing, proper water supply and sanitation, appropriate handling and disposal of solid wastes, safe preparation and storage of food, control of disease vectors in the environment, prevention of risks from chemicals/pesticides and pollution in general, search for and choice of technologies appropriate for the community involved and generation of income for the poor sections of the community. ${ }^{53} \mathrm{~A}$ healthy city is a place where children are nurtured in the body and mind; where the environment invites learning and leisure; where people work and age with dignity; where ecological balance is a source of pride. A healthy city is one that is continually creating and improving those physical and social environments and expanding those community resources, which enable people to mutually support each other in performing all functions of life and in developing their maximum potential.

\section{Expanding the Role of Courts in Protecting Environmental Rights of the Public}

It is undeniable that environmental degradation could eventually endanger the environment and public health of the present and the future generations. Therefore, some of the courts have interpreted the right to life provision in the Constitution in a diversified and advanced way so as to promote environmental protection. The courts in India, Pakistan and Bangladesh use various constitutional rights to protect the environment and promote protection of human rights. The judges are incorporating the right to healthy environment directly or indirectly into their judgments. Developments in conferring environmental rights in the Constitution can assure rights of interested citizens

\footnotetext{
${ }^{52}$ Trudy Harpham, Salma Burton and Ilona Blue, "Healthy city projects in developing countries,: the first evaluation," in Health Promotion International, Vol. 16, No.2, pp.111-125, June 2001, Oxford University Press, 2001 Internet Edition at http://heapro.oxfordjournals.org/cgi/content/full/16/2/111. Accessed on 9th February, 2007.

${ }^{53}$ WHO-CEHA Regional Center for Environmental Health Activities from Internet Edition http://www.ajph.org/cgi/content/abstract/93/1/118?etoc.
} 
to seek relief for environmental harm. This right embedded once in the Constitution of a country will eliminate problems posed by the strict rules of standing that allow only those with sufficient interests to institute an action to demand relief for the damage to his self or his property. The idea of environmental rights emerged from a statement supporting the principle of the human right to environmental quality in the Stockholm Declaration on the Human Environment in 1972:

\begin{abstract}
"[m]an has the fundamental right to freedom, equality and adequate conditions of life, in an environment of a quality that permits a life of dignity and well-being, and he bears a solemn responsibility to protect and improve the environment for present and future generations." 54
\end{abstract}

Further, the Rio Declaration conferred rights on the people to protect the environment, by proclaiming that all human beings have the fundamental right to an environment adequate for their health and well being. ${ }^{55}$ It is generally understood that although environmental rights may be derived from existing treaty rights such as the right to life, health, and property, international law has not incorporated an independent right to environmental quality. ${ }^{56}$ Environmental rights include the right to be free from environmental conditions that threaten health and life itself. ${ }^{57}$ Environmental rights can be conferred on citizens by statutory and constitutional provisions and this right can be invoked before a court of law in the event that it can be proven that the rights have been infringed.

There is no express recognition of a right to environmental quality or protection in the Malaysian Federal Constitution 1957. Yet the absence of an explicit reference to the environment does not preclude argument that environmental rights exist implicitly within other constitutional provisions. The right to life and personal liberty is entrenched in article 5(1) Federal Constitution that provides, no person shall be deprived of his life or personal liberty save in accordance with law." Article 8(1) of the Federal Constitution further provides that all persons are equal before the law and entitled to the equal protection of

54 Declaration on the United Nations Conference on the Human Environment and Development, Our Common Future (Oxford, Oxford University Press, 1987) at p.348.

55 Ibid.

56 Birnie, P.W. \& Boyle, A.E., International Law and the Environment,(Oxford, Clarendon Press, 1992) at p.192.

${ }^{57}$ Aguilar, A.F. \& Popovic, N.A.F., "Law Making in the United Nations: The UN Study on Human Rights and the Environment,"[1994] Review of European Community \& International Environmental Law, Vol.3 (4) at pp.197-205. 
the law. ${ }^{58}$ The provision of article $5(1)$ Federal Constitution can be read as guaranteeing natural justice where the citizens are guaranteed the right to life, which should encompass the right to a clean and healthy environment. ${ }^{59}$ Article 8 (1) Federal Constitution can be read as guaranteeing equality before the law for all persons as well as equal protection in law. Granting equal protection and rights to each and every person can also guarantee an equally healthy environment for all. Though the literacy rate in Malaysia is high compared to many other developing nations, there are still natives (orang as $i$ ) of West and East Malaysia who have yet to be touched by modern development. These people need equal protection from the law especially in terms of preventing logging and other land development activities from threatening their health and livelihood. The natives have special connection to the land they live in. To them it is a source of livelihood and they reserve the right to live peacefully and not be threatened by allowing development to be carried out by the privileged few.

The Malaysian constitution provides for a federal structure that inhibits concerted environmental policy development at both federal and state level. ${ }^{60}$ Harding is of the view that the right to a healthy environment can be given some practical force by a proper division of environmental responsibilities between states and central government. ${ }^{61}$ The Constitution guarantees an institutional structure, which may help to enable issues of environmental human rights to be ventilated through for example, judicial independence and representative parliamentary democracy. ${ }^{62}$ However, legal institutions have constantly been under attack from the executive branch of the Government. ${ }^{63}$ This resulted in concentration of power within the executive sector that has been absorbing most of the powers of the judiciary and legislature.

However, some interesting and commendable developments have taken place in Asian countries. India, Pakistan and Bangladesh interpreted the right to life, as a fundamental right, has been extended to include the right to a healthy

${ }^{58}$ Article $8(1)$ of the Federal Constitution of Malaysia, 1957.

59 Refer Abdul Haseeb Ansary, "Right to Healthful Environment as a means to ensure Environmental Justice: An Overview with Special Reference to India, Philippines and Malaysia" [1998] 4 MLJ xxv.

${ }^{60}$ Harding, A.J., "Practical Human Rights, NGOs \& the Environment in Malaysia," in Boyle, A.E. \& Anderson, M.R.,(eds.) Human Right Approaches to Environmental Protection, (Oxford, Clarendon, 1996) p.227 at p.229.

${ }^{61}$ Ibid. A good example of the concentration of powers on the State or the Central government is the Bakun Dam case.

62 Ibid at p. 230 .

${ }^{63}$ Harding, A.J., "The 1988 Constitutional Crisis in Malaysia," (1990) 39 International and Commonwealth Law Quarterly, at p.57. 
environment. The right to a healthy environment has been incorporated, directly or indirectly, by the court in its' judgements. In India, the constitution provides direct protection for the environment. On the other hand, the Constitution of Bangladesh or Pakistan does not provide any direct protection of the environment. In India, Pakistan and Bangladesh, the fundamental right to life has been expanded to include, amongst others, right to liberty, livelihood, healthy/clean environment or protection against degrading treatment. Most litigation is brought against public authorities, which include various ministries of Central government, federal bodies in Pakistan and India, local authorities and public-owned companies.

The right to life has been used in a diversified manner in India ${ }^{64}$ It includes, inter alia, the right to survive as a species, quality of life, the right to live with dignity and the right to livelihood. In India, this has been expressly recognised as a constitutional right. However, the nature and extent of this right is not similar to the self-executory and actionable right to a sound and healthy ecology prescribed in the Constitution of the Philippines. ${ }^{65}$ Article 21 of the Indian Constitution states: 'No person shall be deprived of his life or personal liberty except according to procedures established by law.' The Supreme Court expanded this negative right in two ways. Firstly, any law affecting personal liberty should be reasonable, fair and just. ${ }^{66}$ Secondly, the Court recognised

64 Jona Razzaque, "Human Rights and the Environment: the national experience in South Asia and Africa", Background Paper No. 4, Joint UNEP-OHCHR Expert Seminar on Human Rights and the Environment, 14-16 January 2002, Geneva (where the discussion reviewed the implementation of Agenda 21 with regard to the promotion and protection of human rights) internet Edition at http://www.unhchr.ch/environment/bp4.html accessed on $20^{\text {th }}$ January 2007; Refer also Professor Dinah Shelton, University of Notre Dame, Human Rights and the Environment: Jurisprudence of Human Rights Bodies, Background Paper No.2, Joint UNEP-OHCHR Expert Seminar on Human Rights and the Environment, 14-16 January 2002, Geneva (where the discussion summarizes the decisions, recommendations and comments of global and regional human rights bodies on issues of environmental protection and human rights), internet Edition at http://www.unhchr.ch/environment/bp2.html, accessed on $20^{\text {th }}$ January 2007 .

${ }^{65}$ Section 16, Article II of the 1987 Constitution states: "The State shall protect and advance the right of the people to a balanced and healthful ecology in accord with the rhythm and harmony of nature'. This right along with Right to Health (section 15) ascertains a balanced and healthful ecology. Minors Oposa v. Sec. of the Department of Environment, 33 LLM 173 (1994) See Antonio G.M. La Vina, 'The Right to a Sound Environment in the Philippines: The Significance of the Minors Oposa Case' (1994) RECIEL Vol 3, No.4, pg.246-252.

${ }^{66}$ Maneka Gandhi v. Union of India, AIR 1978 SC 597, 623-624. Francis Coralie Mullin v. The Administrator, Union Territory of Delhi, AIR 1981 SC 746, 749-750. 
several unarticulated liberties that were implied by article $21 .^{67}$ It is by this second method that the Supreme Court interpreted the right to life and personal liberty to include the right to a clean environment. ${ }^{68}$

In Vellore Citizens Welfare Reform $v$. Union of India, ${ }^{69}$ the discussion on life and liberty rights afforded by the Indian Constitution and the constitutional mandate to the state to protect and improve the environment and public health. The Indian Supreme Court determined that a number of tanneries in the State of Tamil Nadu violated citizens' right to life by discharging untreated effluents into agricultural areas and local drinking water supplies. Imposing pollution fines on certain tanneries to be utilized for compensating affected individuals and restoring environmental damages caused by the tanneries.

In Re Human Rights Case ${ }^{70}$ the reasoning that dumping waste materials along the coasts, including nuclear waste, could jeopardize the people's health, environment, and marine life in the region was accepted by the courts. In $S e c ' y$, West Pak. Salt Miners Labour Union v. Dir., Indus. \& Mineral Dev., ${ }^{71}$ the Judge determined that mining operations posed dangers of contamination because such operations could cause cracks, punctures, and leakages in the rocks and ravines that would contaminate or dry up the water springs. The Pakistani Supreme Court explained that the right to life under the Constitution entailed an expansive definition and thus, includes the right to have access to unpolluted water. The Malaysian courts can definitely learn from the other Asian counterparts so that it too can help enforce environmental rights and promotion of public health.

\section{CONCLUSIONS}

The link between the environment and public health can never be severed and history proves that attempts to severe the link has cause unnecessary problems to man's well being. Until very recently, environmental protection, public

${ }^{67}$ Directive principle such as equal pay for equal work, free legal aid, right to speedy trial, right to livelihood, right to education and DP relating to environment [Aricle 48$\mathrm{A}]$ are read in conjunction with the fundamental rights.

${ }_{68}^{6}$ P. Leelakrishnan, Law and Environment (1992, Eastern Book Company, India) Chapter 10, pg.144-152.

${ }^{69}$ Vellore Citizens Welfare Reform v. Union of India, A.I.R. 1996 S.C. 2715, 2721.

${ }^{70}$ Re Human Rights Case, P.L.D. 1994 S. Ct. 102.

${ }^{71}$ Gen. Sec'y, West Pak. Salt Miners Labour Union v. Dir., Indus. \& Mineral Dev., 1994 S.C.M.R. 2061. 
health and human rights were viewed as distinct areas of public policy by governmental institutions and non-governmental organizations alike at both the national and international levels. With increasing globalization of trade and commerce in the past few decades, the environmental and public health impacts of rapid industrialization and urbanization in different regions of the world are now recognized as having major human rights implications by many policy makers. Human rights in the context of environment and sustainable development recognize that for human communities to survive, they must have an adequate and secure standard of living; they must be protected from harmful substances and unsafe products; they must learn to conserve and equitably share natural resources. Without these environmental and public health policies in place, human rights for respect, dignity, equality, non-discrimination and the ability for the public to participate in decisions that affect their lives cannot be achieved. Thus, the role of the local authorities and public health in improving public health must be seriously considered.

\section{REFERENCES:}

Watts, R.L., 1966. New Federations: Experiments in the Commonwealth. Oxford: Clarendon Press.

Perdue, W.C., Stone, L.A., Gostin L.O, 2003. "The Built Environment and Its Relationship to the Public's Health: The Legal Framework," September 2003, Vol.93, No.9 American Journal of Public Health $1390-1394$.

Government of Malaysia, "Chapter 1" in Ninth Malaysia Plan 2006 - 2010 , Government of Malaysia.

Melosi, M., 2001. Effluent America: Cities, Industry, Energy, and the Environment. Pittsburgh, Pa: University of Pittsburgh Press.

MacKenzie, W., Hoxie, N., Proctor, M., Gradus, M., Blair, K., Peterson, D., 1994. "A massive outbreak in Milwaukee of Cryptosporidium infection transmitted through public water supply" $N$ Engl J Med.1994; 331:161167.

Ahmad Kamal Ariffin Mohd Rus, 2001. Sanitary Board Kuala Lumpur Peranan dan Pentadbiran 1890-1914, Persatuan Sejarah Malaysia, Kuala Lumpur.

Public Health in Land Use Planning and Community Design, fact sheet of the National Association of County and City Health Officials, 2005.

Preamble to the Constitution of the World Health Organization as adopted by the International Health Conference, 1946.

World Resources Institute [WRI] et al., World Resources 1998-99, at 67 (1998) stating that climate influences many health determinants and while 
substantial climate-related health effects are predicted for the future, making such predictions is an inexact science.

WHO Regional Office for Europe [WHO ROE], Environment and Health: The European Charter and Commentary (1989).

Smith, K.R. et al., 1999. "How Much Ill Health Is Attributable to Environmental Factors?"10 Epidemiology 573, 573, 581-83

WHO, "Health in the Context of Sustainable Development," at 67, WHO Doc. WHO/HDE/HID/02.6 (2002) (prepared by Y. von Schirnding \& C. Mulholland)

Onzivu, W., 2006. "International Environmental Law, the Public's Health, and Domestic Environmental Governance in Developing Countries,"21 American University International Law Review. p.597, at p.603.

WHO Press Release, "Avian Influenza - Situation (Birds) in Nigeria," Feb. 8, 2006, http://www.who.int/csr/don/2006 02 08/en/

Onzivu, W., 2006. "Globalism, Regionalism, or Both: Health Policy and Regional Economic Integration in Developing Countries, an Evolution of a Legal Regime?", 15 Minn. J. Int'l L. 111, 115

Pearl, M.C., 2004. "Editorial, Wildlife Trade: Threat to Global Health," 1 Eco Health 111

Duhl, L.J., Sanchez, A.K., Healthy Cities and the City Planning Process, Internet Edition at http://www.who.dk/docment 843pdf. Accessed on 20th November 2006.

Healthy People 2010, 2000. Washington, DC.: US Dept of Health and Human Services.

Coburn J., "Confronting the Challenges in Reconnecting Urban Planning and

Public Health," in American Journal of Public Health, 2004 April; 94(4):541-546.

1992. Report of the United Nations Conference on Environment and Development, June 3-14, 1992, Rio Declaration on Environment and Development, Annex I principle No. 4, U.N. Doc A/CONF.151/26 (Vol. I) ["Rio Declaration"].

1973. United Nations Conference on the Human Environment, June 5-16, 1972, Declaration of the United Nations Conference on the Human Environment, Principle No.1, U.N. Doc. A/CONF.48/14/Rev.1["Stockholm Declaration"]

Onzivu, W., "International Environmental Law, the Public's Health, and Domestic Environmental Governance in Developing Countries," 2006, 21 Am. U. Int'l L. Rev. 597 at p.14

Constitution of the World Health Organization, July 22, 1946, 62 Stat. 2679, 14 U.N.T.S. 185.

Grad, F.P., 1998. "Public Health Law: Its Form, Function, Future, and Ethical Parameters," 49 Int'l Digest Health Legis. 19, 19-22; 
Onzivu, W.,2001. Public Health and the Tobacco Problem: International Legal Implications for Africa, 29 Ga. J. Int'l \& Comp. L. 223, 225.

Nanda, V.P., and Pring, G., 2003. International Environmental Law for the 21st Century 17-62;103.

Von Schirnding, Y., et al., 2002. "International Environmental Law and Global Public Health", 80 Bull. World Health Org; 970, 972-73

WHO-CEHA Regional Center for Environmental Health Activities from Internet Edition http:/www.ajph.org/cgi/content/abstract/ 93/1/118?etoc

Declaration on the United Nations Conference on the Human Environment and Development, Our Common Future (Oxford, Oxford University Press, 1987) at p.348.

Birnie, P.W., \& Boyle, A.E., 1992. International Law and the Environment. Oxford: Clarendon Press.

Aguilar, A.F. \& Popovic, N.A.F., 1994. "Law Making in the United Nations: The UN Study on Human Rights and the Environment,"Review of European Community \& International Environmental Law, Vol.3 (4);197205.

Abdul Haseeb Ansary, 1998. "Right to Healthful Environment as a means to ensure Environmental Justice: An Overview with Special Reference to India, Phillipines and Malaysia" 4 MLJ xxv

Harding, A.J., "Practical Human Rights, NGOs \& the Environment in Malaysia," in Boyle, A.E. \& Anderson, M.R.,(eds.), 1996. Human Right Approaches to Environmental Protection. Oxford: Clarendon; 227,229.

Harding, A.J., 1990. "The 1988 Constitutional Crisis in Malaysia," International and Commonwealth Law Quarterly; 57.

Leelakrishnan, P., 1992. Law and Environment. Eastern Book Company: India; 144-152

Knetsch, J.L., "Law and Social Sciences: Reciprocal Influences and Opportunities", in Anthony Chin and Alfred Choi (eds.) Law, Social Sciences and Public Policy - Towards a Unified Framework, Centre for Advanced Studies, National University of Singapore, Singapore University Press, pp. 11-22. 